\title{
a-tocopheryl phosphate suppresses tumor invasion concurrently with dynamic morphological changes and delocalization of cortactin from invadopodia
}

\author{
YASUKAZU SAITOH, ATSUSHI YUMOTO and NOBUHIKO MIWA
}

Cell-Death Control BioTechnology Laboratory, Faculty of Life and Environmental Sciences, Prefectural University of Hiroshima, Nanatsuka 562, Shobara, Hiroshima 727-0023, Japan

Received July 9, 2009; Accepted September 7, 2009

DOI: 10.3892/ijo_00000445

\begin{abstract}
TocP) has been elucidated for diverse effectiveness through unequivocal mechanisms independent of its conversion to $\alpha$-tocopherol (Toc). The present study showed that TocP, in a dose-dependent manner, repressed invasion of human fibrosarcoma HT-1080 cells through the basement membrane, more markedly than Toc and several other Toc derivatives, although no cytotoxic effect was shown in either HT-1080 cells or human skin dermal fibroblastic cells DUMS-16. TocP diminished intracellular reactive oxygen species such as peroxides, lipid hydroperoxides and superoxide anion radicals in HT-1080 cells, but the effects were nearly equal or less than those of Toc. TocP suppressed either the cell motility or adhesion to extracellular matrix (ECM), and induced diagnostic morphological changes such as appearance of numerous spikeshaped processes and vesicles. Localization of cortactin in the membrane of invadopodia, which dispatches signal transduction for tumor invasion, was lost by TocP as shown by immunostaining. Similar result was obtained also by Western blots showing that cortactin in the membrane fraction was markedly diminished by TocP in contrast to unchanged cortactin amounts in other subcellular fractions including nuclei, cytoplasms and cytoskeletons. In contrast, TocP scarcely affected the invasiveness-related gelatinases MMP-2/9 and cell membrane fluidity. Thus, TocP markedly exerted anti-invasive activities through decrease in cell motility, repression of adhesion to the ECM, cell morphological changes and, especially, alteration of cortactin distribution. Moreover, TocP also preferentially inhibited tumor invasion without cytotoxicity to normal cells derived from the
\end{abstract}

Correspondence to: Professor Nobuhiko Miwa, Cell-Death Control BioTechnology Laboratory, Faculty of Life and Environmental Sciences, Prefectural University of Hiroshima, Nanatsuka, Shobara, Hiroshima 727-0023, Japan

E-mail: miwa-nob@pu-hiroshima.ac.jp

Key words: $\alpha$-tocopheryl phosphate, tumor cell, invasion, cortactin, invadopodia corresponding tissue type. Consequently, TocP is suggested as a potent tumor-invasion suppressor.

\section{Introduction}

$\alpha$-tocopheryl phosphate ester (TocP), an $\alpha$-tocopherol (Toc) derivative esterified with a chroman hydroxyl group by phosphate, has been found in foodstuffs, plant and animal tissues, including human tissues (1), and described as a novel natural form of Toc $(2,3)$. TocP has properties different from those of Toc, such as stability against oxidation and solubility in aqueous solutions due to the esterified phosphoric acid (4).

Recently, TocP has been demonstrated for the biological and/or physiological effectiveness. For example, TocP can reduce myocardial ischemia/reperfusion injury (5), protect against ultraviolet B-induced damage in cultured mouse skin (6), suppress lipid peroxidation and induction of erythrocyte hemolysis (7), induce cell death, inhibit cell proliferation and provoke apoptosis in osteosarcoma cells (3), down-regulate the scavenger receptor CD36 $(4,8,9)$, and exert atheroscleroticpreventing effects $(8,9)$. Furthermore, several studies have also indicated that TocP has been shown to be more effective than Toc in the regulation of cell properties $(4,8-10)$. Thus, the possibility that the active form of Toc may be TocP has been considered $(4,9)$. Although various effects of TocP have been reported as mentioned above, little is known about its anti-cancer effects.

Tumor invasion and metastasis are known as direct major mortal causes of cancer patients, and so these occurrences are critical issues, which should be overcome for cancerrecurrence prevention and cancer therapy (11). The invasion of tumor cells through the basement membrane (BM) is a crucial step in the execution of metastasis. Therefore, the present investigations aimed at determining whether the invasion of tumor cells through the BM is inhibited by TocP. In the present study, we found that TocP markedly inhibited the tumor invasion as compared with other various Toc derivatives. In addition, we further demonstrate evidence that the effects of TocP on tumor invasion are through decrease in cell motility, repression of adhesion to the extracellular matrix (ECM), cell morphological changes and a drastic alteration of cortactin distribution at invadopodia. 


\section{Materials and methods}

Cell culture. Human fibrosarcoma HT-1080 cells (12) were obtained from Japanese Cancer Research Resource Bank (JCRB, Osaka, Japan), and human skin dermal fibroblasts DUMS-16 were kindly supplied by Professor Masayoshi Namba of Niimi College. Cells were cultured in Eagle's minimum essential medium (MEM; Nissui Seiyaku, Tokyo) supplemented with $10 \%$ heat-inactivated fetal bovine serum (FBS, Biological Industries Ltd., Beit Haemek, Israel) and $2 \mathrm{mM}$ L-glutamine. Cells were cultured at $37^{\circ} \mathrm{C}$ in a humidified atmosphere of $95 \%$ air and $5 \% \mathrm{CO}_{2}$.

Invasion assay. Invasiveness of HT-1080 cells into the reconstituted $\mathrm{BM}$ Matrigel ${ }^{\mathrm{TM}}$ (BD Biosciences, MA, USA) was determined as described previously $(13,14)$. Briefly, cells were detached with phosphate-buffered saline (PBS)EDTA and gently pipetted to form single-cell suspension in culture medium. Then, cells $\left(7.0 \times 10^{5}\right)$ were mixed with culture medium containing the indicated concentrations of several Toc derivatives; Toc (Sigma, MO, USA), TocP (sodium $\alpha$-tocopheryl phosphate; Showa Denko Co. Ltd., Tokyo) (Fig. 1), $\alpha$-tocopheryl acetate (TocA) (Eisai Co. Ltd., Tokyo), $\alpha$-tocopheryl nicotinate (TocN) (Sigma), $\alpha$-tocopheryl succinate (TocS) (Sigma) and $\alpha$-tocopheryl N,N-dimethylglcinate (TDMG) (Showa Denko Co. Ltd.). Except for TocP, other Toc derivatives were dispersed in the medium containing Pluronic ${ }^{\circledR}$ F-68 (Sigma) at a final concentration of $0.2 \%$. Cells were incubated by gentle stirring with a rotator ( 5 rounds $/ \mathrm{min}$ ) at $37^{\circ} \mathrm{C}$ for $1 \mathrm{~h}$, and then cell suspensions were added to the upper compartments of filter basket chambers (cell culture insert, BD Biosciences). In each chamber, the culture medium containing the same concentration of TocP was added to the lower compartment of a chamber as well as the upper compartment. After 1-h incubation at $37^{\circ} \mathrm{C}$, cells that invaded through the Matrigelprecoated membrane filter with $8-\mu \mathrm{m}$ pores (BD Biosciences) were stained with Diff-Quik (Sysmex, Kobe, Japan) and counted under a microscope.

Evaluation of cell viability. Cell viability was assessed based on mitochondrial enzymatic conversion of WST-1 [2-(4iodophenyl)-3-(4-nitrophenyl)-5-(2.4-disulfophenyl)-2Htetrazolium, sodium salt] (Dojindo, Kumamoto, Japan) to yellowish formazan, which is indicative of viable cells. Cells were seeded at a density of $2.0 \times 10^{5}$ cells/well in the Matrigelprecoated 24-well plate. After 24-h incubation, the medium was exchanged to fresh cell culture media containing Toc or TocP $(0-500 \mu \mathrm{M})$. After 2-h incubation, cells were rinsed with phenol red (PR)-free medium and then incubated for $3 \mathrm{~h}$ in PR-free MEM containing $5 \mathrm{mM}$ WST-1 and $0.2 \mathrm{mM}$ 1-methoxy-5-methylphenazinium methylsulfate at $37^{\circ} \mathrm{C}$. The absorbance at $450 \mathrm{~nm}$ was measured with a microplate reader (FLUOstar OPTIMA, BMG Labtech, Offenburg, Germany). The cell viability is expressed as a percentage versus that of the control cells.

Measurement of intracellular peroxide production. Intracellular ROS production was determined based on oxidative conversion of 6-carboxy-2', 7'-dichlorodihydrofluorescein diacetate, di (acetoxymethyl ester) (CDCFH-DA) (Molecular Probes, OR, USA) to CDCF, which is indicative of the amount of intracellular peroxide production such as hydroperoxides, hydrogen peroxides and diverse peroxides. Cells were detached with PBS-EDTA and gently pipetted to form singlecell suspension in culture medium. Then, cells $\left(7.0 \times 10^{5}\right)$ were mixed with culture medium containing Toc or TocP, and incubated by gentle stirring with a rotator $(5$ rounds $/ \mathrm{min}$ ) at $37^{\circ} \mathrm{C}$. After $1-\mathrm{h}$ incubation, cells were seeded into the Matrigel-precoated culture plate and incubated for $1 \mathrm{~h}$ in PRfree MEM containing $50 \mu \mathrm{M}$ CDCFH-DA at $37^{\circ} \mathrm{C}$. Cells were rinsed with PR-free MEM, and the fluorescence intensity was measured with a fluorescence microplate reader (FLUOstar OPTIMA) with excitation and emission wavelengths of 485 and $530 \mathrm{~nm}$, respectively.

Determination of intracellular lipid hydroperoxides. Intracellular lipid hydroperoxides were detected using the fluorescence probe diphenyl-1-pyrenylphosphine (DPPP; Dojindo) as described previously (15) with a slight modification. Briefly, cells were detached with PBS-EDTA and gently pipetted to form single-cell suspension in culture medium. Then, cells $\left(7.0 \times 10^{5}\right)$ were mixed with PR-free MEM containing DPPP at a final concentration of $50 \mu \mathrm{M}$, and the cell suspension was incubated by gentle stirring with a rotator ( 5 rounds $/ \mathrm{min}$ ) at $37^{\circ} \mathrm{C}$. After $30-\mathrm{min}$ incubation, cell suspensions were washed with PR-free MEM twice and incubated in the PR-free MEM containing Toc or TocP similarly by stirring. After 1-h incubation, the cell suspensions were seeded into the Matrigel-precoated culture plate and further incubated for $1 \mathrm{~h}$. The fluorescence intensities were measured with the Varioskan Flash 2.4 (Thermo Fisher Scientific K.K., Yokohama, Japan) with excitation and emission wave lengths of 351 and $380 \mathrm{~nm}$, respectively.

Measurement of intracellular generation of superoxide anion radicals. Superoxide generation was detected by nitroblue tetrazolium (NBT) assay (16). NBT (yellow, water-soluble) (Wako Pure Chemical Industries Ltd., Osaka, Japan) was reduced by superoxide anion radicals to form formazan-NBT (dark-blue, water-insoluble). Cells were seeded at a density of $2.0 \times 10^{4}$ cells/well in the Matrigel-precoated 24-well plate. After 24-h incubation, the medium was exchanged to fresh cell culture media containing Toc or TocP (0-500 $\mu \mathrm{M})$. After 90-min incubation, cells were rinsed with PR-free MEM and incubated for $90 \mathrm{~min}$ in PR-free DMEM containing $0.2 \%$ NBT. Cells were rinsed with cold PBS, stained and photographed. Then, the formazan was dissolved in $2 \mathrm{M} \mathrm{KOH} /$ DMSO solution for $30 \mathrm{~min}$ at $37^{\circ} \mathrm{C}$, and the absorbance was determined at $680 \mathrm{~nm}$.

Cell migration assay. To determine cell migratory activity of tumor cells, we performed a wound-migration assay, as described previously (17). HT-1080 cells were seeded at a density of $2.0 \times 10^{5}$ cells/well into a Matrigel-precoated 24-well plate. When cells were confluent, cells were treated with $0-500 \mu \mathrm{M}$ of TocP, and incubated for 0,2 , or $4 \mathrm{~h}$. Then, cell monolayers were wounded with $10 \mu 1$ micropipette tip, washed twice with medium, and treated with $0-500 \mu \mathrm{M}$ of TocP. After 4-h incubation, cells were washed twice with 
PBS and then fixed with Diff-Quik solution. Migration was quantified by counting the number of cells that migrated from the wounded edge into the denuded area for distances of approximately $150-200 \mu \mathrm{m}$.

Cell-matrix and cell-cell adhesion assay. Cells were detached with PBS-EDTA and gently pipetted to form single-cell suspension in culture medium. Then, cells $\left(7.0 \times 10^{5}\right)$ were mixed with culture medium containing Toc or TocP, and incubated for $1 \mathrm{~h}$ by gentle stirring with a rotator (5 rounds $/ \mathrm{min}$ ) at $37^{\circ} \mathrm{C}$. In cell-matrix assays, treated cells were seeded at a density of $1.0 \times 10^{6}$ cells/well into a Matrigelprecoated culture plate and incubated for $1 \mathrm{~h}$ at $37^{\circ} \mathrm{C}$. Then, non- or weakly-adherent cells were collected by repeated rinsing with culture medium. The number of detached cells was measured with a particle counter (CDA-500, Sysmex, Kobe, Japan), and the attached-cell number was calculated as the difference between detached cells and seeded cells. Cellcell adhesion assays were performed by preparing 24-well plates covered with HT-1080 cells in full confluency. TocPtreated cells $\left(1.0 \times 10^{6}\right)$ were seeded additionally. After 1 -h incubation, the non-adherent cells were harvested, and the cell number was measured with a particle counter.

Zymography. Activities of MMPs secreted from HT-1080 cells were analyzed by gelatin zymography. Cells were detached with PBS-EDTA and gently pipetted to form singlecell suspension in culture medium. Then, cells $\left(7.0 \times 10^{5}\right)$ were mixed with culture medium containing indicated concentrations of TocP $(0-500 \mu \mathrm{M})$, and incubated by gentle stirring with a rotator $(5$ rounds $/ \mathrm{min})$ at $37^{\circ} \mathrm{C}$ for $1 \mathrm{~h}$. Treated cells were seeded into a 24 -well plate, and incubated at $37^{\circ} \mathrm{C}$. After 1- or 24-h incubation, the supernatant was collected as conditioned medium, and the protein concentrations were determined using DC protein assay kit (Bio-Rad, Hercules, CA, USA). The conditioned medium was mixed with Trisglycine SDS sample buffer (Invitrogen Corporation, CA, USA) without heating or reduction, and applied to $10 \%$ polyacrylamide gels copolymerized with $0.1 \%$ gelatin (Invitrogen Corporation). After electrophoresis, gels were washed for $30 \mathrm{~min}$ at the room temperature in zymogram renaturing buffer (Invitrogen Corporation), and then incubated in zymogram developing buffer (Invitrogen Corporation) for $16 \mathrm{~h}$ at $27^{\circ} \mathrm{C}$. Subsequently, gels were fixed and stained with $10 \%$ methanol and $10 \%$ acetic acid containing $0.5 \%$ Coomassie brilliant blue R250. The protease activity was visualized as transparent bands on the stained gel.

Cell membrane fluidity. The membrane fluidity of HT-1080 cells was measured by electron spin resonance (ESR). Singlecell suspension prepared as above-mentioned $\left(8.0 \times 10^{6}\right)$ was mixed with culture medium containing TocP, and incubated similarly as above-mentioned. After 1-h incubation, spin labeled 5-doxylstearic acid (5-DS; Sigma) or 16-doxylstearic acid (16-DS; Sigma) was added to the cell suspensions, and they were incubated for $45 \mathrm{~min}$ at $37^{\circ} \mathrm{C}$. Then, ESR measurements were performed using an ESR spectrometer (type JESER30, JOEL, Tokyo) under the following conditions: magnetic field $336 \pm 5 \mathrm{mT}$; $4 \mathrm{~mW}$ microwave power; sweep time $8 \mathrm{~min}$; modulation width $0.2 \mathrm{mT}$; amplification 400, and
$1.0 \mathrm{sec}$ time constant. Membrane fluidity was calculated from the order parameter (S) and peak height ratio (ho/h-1) as described previously $(7,18)$.

Scanning electron microscopy (SEM). HT-1080 or DUMS-16 cells were seeded onto Matrigel-precoated plastic sheets (Wako Pure Chemical Industries Ltd.) at a cell density of $2.0 \times 10^{5}$. After $24-\mathrm{h}$ incubation, cells were treated with TocP for $2 \mathrm{~h}$ at $37^{\circ} \mathrm{C}$. Cells were fixed with Karnowsky's modified solution $(2.5 \%$ glutaraldehyde and $2 \%$ paraformaldhyde in $0.1 \mathrm{M}$ phosphate buffer, $\mathrm{pH}$ 7.4) for $90 \mathrm{~min}$, and then the cells were rinsed six times with $0.1 \mathrm{M}$ phosphate buffer, postfixed for $90 \mathrm{~min}$ with $1 \% \mathrm{Os}_{2} \mathrm{O}_{4}$ in $0.1 \mathrm{M}$ phosphate buffer, dehydrated in graded alcohols, subjected to critical point drying, and sputter-coated with gold palladium. The samples were examined with a scanning electron microscope (VE-9800, Keyence Corporation, Osaka, Japan).

Immunocytochemical staining of cortactin and F-actin. HT1080 cells were seeded at a density of $3.0 \times 10^{4}$ cells/chamber into the Matrigel-precoated Lab-Tek four chamber glass slides (Nalge Nunc International K.K., Tokyo). After 24-h incubation, cells were treated with $0-500 \mu \mathrm{M}$ of Toc or TocP, washed with PBS, and fixed in a freshly prepared solution of $4 \%$ paraformaldehyde in PBS for $20 \mathrm{~min}$. The cells were permeabilized in PBS containing $0.5 \%$ Triton X-100 for $8 \mathrm{~min}$, and then washed with PBS twice. Nonspecific binding was blocked by incubating the cells for $30 \mathrm{~min}$ in PBS containing $1 \%$ bovine serum albumin (BSA). Cells were incubated with the rabbit primary antibody against human cortactin (Santa Cruz Biotechnology, CA, USA) diluted at a rate of 1:100 in PBS containing $1 \% \mathrm{BSA}$ for $1 \mathrm{~h}$ at $37^{\circ} \mathrm{C}$. The cells were then washed six times with PBS containing $1 \%$ BSA and incubated with the secondary antibody conjugated with Alexa Fluor ${ }^{\circledR} 488$ against rabbit IgG (Invitrogen Corporation) diluted at 1:500 in PBS containing 1\% BSA, and $100 \mathrm{nM}$ rodamine-conjugated phalloidin (CosmoBio Co., Ltd., Tokyo) for $30 \mathrm{~min}$ at $37^{\circ} \mathrm{C}$. The slides were washed with PBS, mounted with UltraCruz ${ }^{\mathrm{TM}}$ Mounting medium (Santa Cruz Biotechnology), and observed with a fluorescence microscope. Pseudo-color images were produced using AquaCosmos software (Hamamatsu Photonics, Shizuoka, Japan).

Western blot analysis. HT-1080 cells were detached with PBS-EDTA and gently pipetted to form single-cell suspension in culture medium. Then, cells $\left(7.0 \times 10^{5}\right)$ were mixed with culture medium containing $0-500 \mu \mathrm{M}$ of TocP, and incubated for $1 \mathrm{~h}$ similarly by stirring. For preparation of whole cell lysate, cells were washed twice with PBS and lysed with an ice-cold lysis buffer (0.5\% SDS, $50 \mathrm{mM}$ Tris/ $\mathrm{HCl}, \mathrm{pH} 7.4,1 \mathrm{mM}$ DTT). For preparation of subcellular fractions, cells were washed twice with PBS, and each fraction was obtained by using Qproteome Cell Compartment Kit (Qiagen, Inc., Valencia, CA, USA) according to the manufacturer's protocol. After a centrifugation step $(12,000 \mathrm{x} \mathrm{g}$, $4^{\circ} \mathrm{C}, 10 \mathrm{~min}$ ), protein concentrations of the supernatant were determined using DC protein assay kit (Bio-Rad). The total protein amount of $20 \mu \mathrm{g}$ was analyzed by Western blotting under reductive conditions (NuPAGE Novex Bis-Tris 4-12\% 


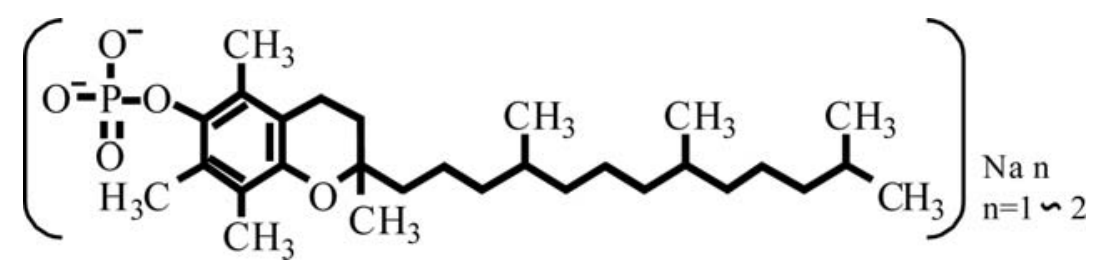

Figure 1. Chemical structure of sodium $d l$ - $\alpha$-tocopheryl phosphate (TocP).
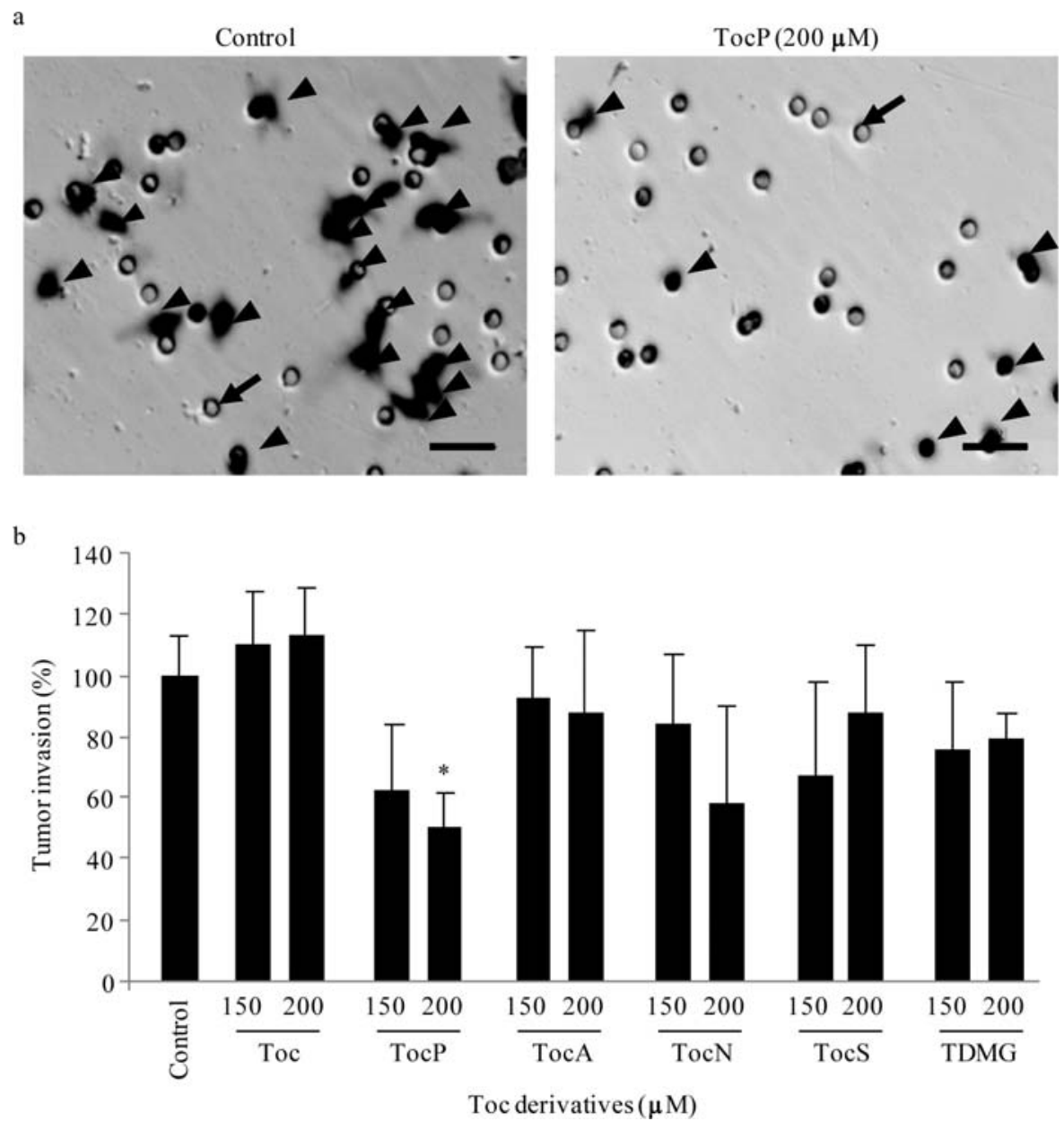

Figure 2. Inhibitory effects of $\alpha$-tocopherol (Toc) derivatives on invasion of human fibrosarcoma HT-1080 cells. Cells were detached to form single-cell suspension in culture medium and treated with 150 or $200 \mu \mathrm{M}$ of several Toc derivatives; Toc, TocP (sodium $\alpha$-tocopheryl phosphate), $\alpha$-tocopheryl acetate (TocA), $\alpha$-tocopheryl nicotinate (TocN), $\alpha$-tocopheryl succinate (TocS), $\alpha$-tocopheryl N,N-dimethylglcinate (TDMG) or vehicle (the control) for $1 \mathrm{~h}$. Then, cell suspension was added to the upper compartment of a filter basket chamber. After 1 - $\mathrm{h}$ incubation at $37^{\circ} \mathrm{C}$, cells that invaded through the Matrigelprecoated membrane filter were stained, photographed (a) and counted under a microscope (b). The photographs show stained cells that completed the invasion through the Matrigel-precoated membrane after 1-h incubation. Significantly different from the control: "p $<0.05$. Arrowhead indicates an invasive cell. Arrow indicates an $8-\mu \mathrm{m}$ pore. The scale bar indicates $25 \mu \mathrm{m}$.

Gels and SDS-PAGE NuPAGE MOPS buffer system, Invitrogen Corporation) using antibodies directed against cortactin, (1:100 dilutions, as used for immunofluorescence staining, see above), and $\beta$-actin (1:100 dilution, polyclonal rabbit anti-human $\beta$-actin, Santa Cruz Biotechnology). Detection was performed with WesternBreeze ${ }^{\circledR}$ Chemiluminescent Detection System (Invitrogen Corporation) for cortactin and $\beta$-actin, and the blots were exposed to Hyperfilm MP (Kodak, Tokyo) for 5 min. Semiquantitative analysis of the data was conducted by the use of Image $\mathbf{J}$ (NIH) software.
Statistical analysis. Data are expressed as mean \pm SD, and statistical comparisons were performed using an unpaired Student's t-test or a Dunnet's multiple comparison test. Differences with $\mathrm{p}<0.05$ were considered to be statistically significant.

\section{Results}

Inhibitory effects of TocP on tumor invasion of human fibrosarcoma HT-1080 cells. It was found that several Toc derivatives inhibited tumor invasion of HT-1080 cells through 


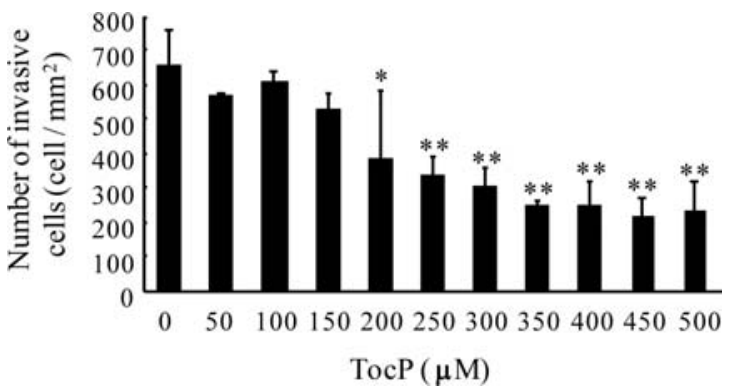

Figure 3. Dose-dependency in inhibitory effects of TocP on invasion of HT1080 cells. Cells were treated with TocP of diverse does as in Fig. 2. Significantly different from $0 \mu \mathrm{M}$ of TocP (the control): ${ }^{*} \mathrm{p}<0.05,{ }^{* *} \mathrm{p}<0.01$.
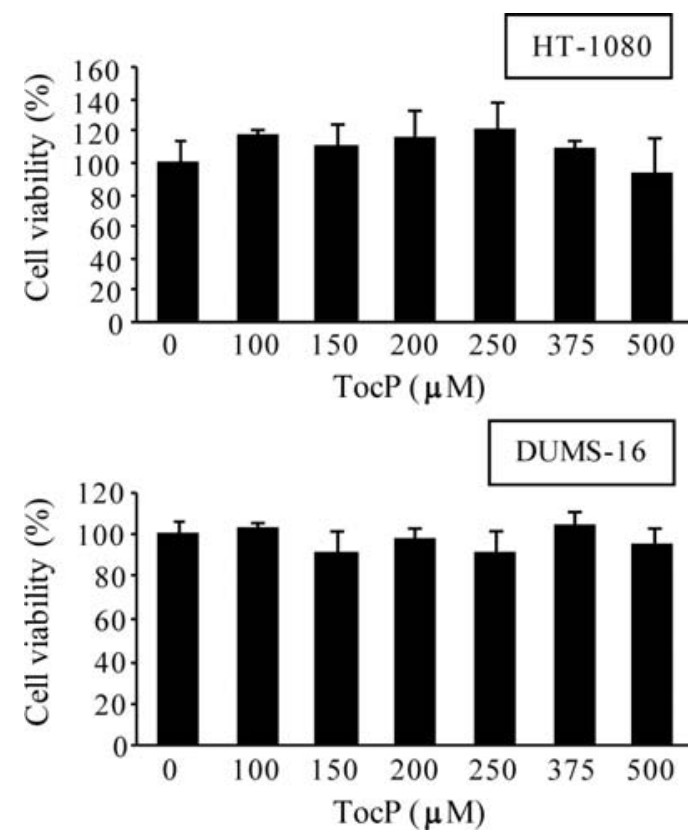

Figure 4. Effects of TocP on cell viability of human fibrosarcoma HT-1080 or human skin dermal fibroblasts DUMS-16 cells. Cells were seeded on the Matrigel-precoated 24-well plate, grown for $24 \mathrm{~h}$. Then, the medium was exchanged to freshly prepared cell culture media containing TocP $(0-500 \mu \mathrm{M})$. After 2-h incubation, cells were rinsed and then incubated for $3 \mathrm{~h}$ in PR-free MEM containing WST- 1 reagents at $37^{\circ} \mathrm{C}$. The absorbance at $450 \mathrm{~nm}$ was measured with a microplate reader.

the reconstituted $\mathrm{BM}$ coated on the upper surface with Matrigel. The reconstituted BM invasion assay was used to estimate the invasive ability of tumor cells. The number of invasive cells was decreased in some Toc derivatives, but TocP was the most effective for tumor invasion $(\mathrm{p}<0.05)$ among the six Toc derivatives examined (Fig. 2). In addition, TocP significantly reduced the number of invasive cells at doses more than $200 \mu \mathrm{M}$, and suppressed the tumor invasion in a dose-dependent manner (Fig. 3).

Effects of TocP on cell viability of human fibrosarcoma HT1080 or human skin dermal fibroblasts DUMS-16 cells. To estimate the cytotoxicity of TocP in human fibrosarcoma HT-1080 or human skin dermal fibroblasts DUMS-16 cells, cells were subjected to TocP treatment $(0-500 \mu \mathrm{M})$ for the same period as for tumor invasion assay, and then each cell

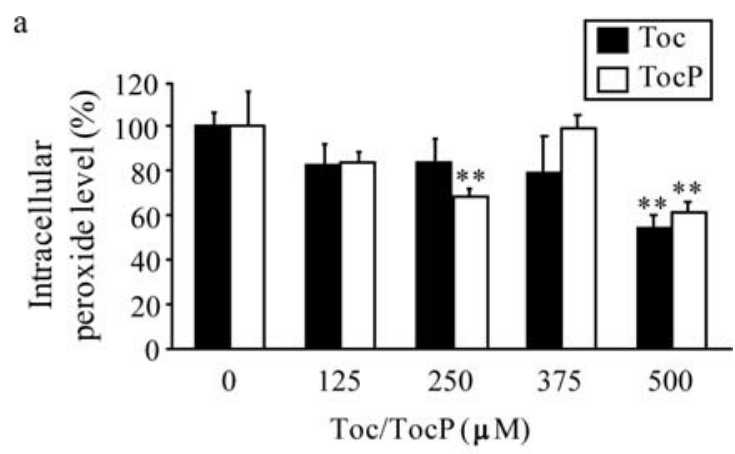

b
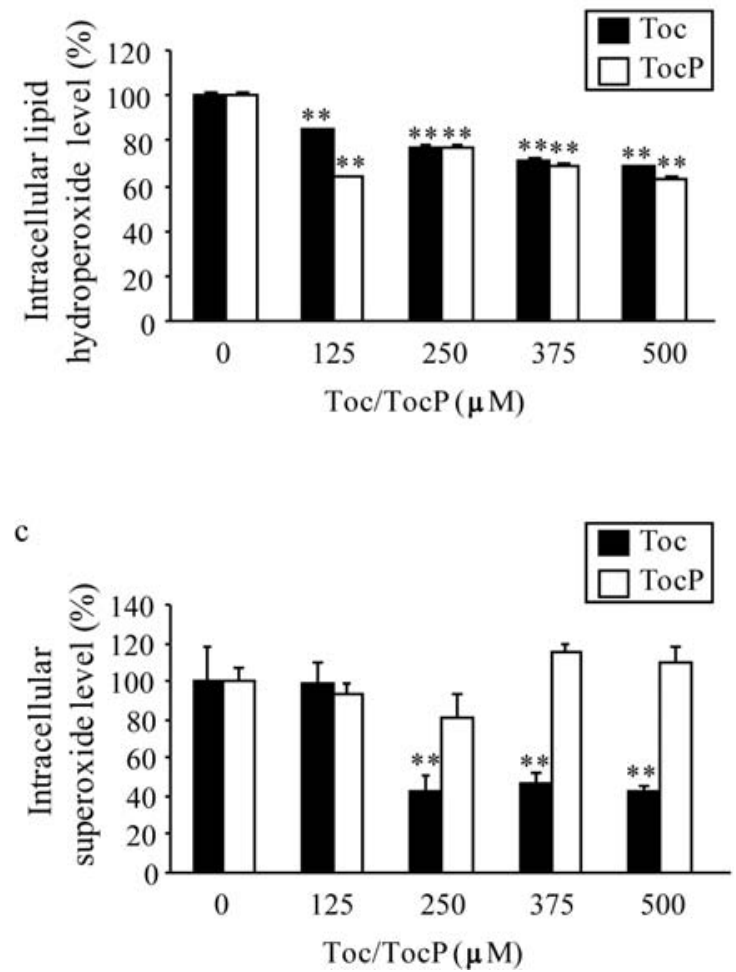

Figure 5. Effects of TocP on generation of intracellular ROS such as peroxides, lipid hydroperoxides and superoxide anion radicals in HT-1080 cells. Cells were treated with Toc $(0-500 \mu \mathrm{M})$ or TocP $(0-500 \mu \mathrm{M})$ for $60-90$ min. Then, levels of intracellular peroxides (a), lipid hydroperoxides (b) and superoxide anion radicals (c) were evaluated. Significantly different from $0 \mu \mathrm{M}$ of TocP (the control): ${ }^{* *} \mathrm{p}<0.01$.

viability was evaluated by WST-1 assay. The cell viability of either cell line was not decreased by any concentrations of TocP (Fig. 4).

Repressive effects of TocP on intracellular reactive oxygen species (ROS) production in HT-1080 cells. To examine whether TocP could prevent intracellular ROS production in HT-1080 cells, we quantified the intracellular levels of ROS such as peroxides, lipidperoxides and superoxide anion radicals, by fluorometry using CDCFH-DA and DPPP, and photometric NBT, respectively. The results showed that intracellular peroxide and lipidperoxide levels markedly decreased by Toc- or TocP-treatment in a dose-dependent manner $(p<0.01)$ (Fig. 5a and b). These repressive effects were equally given at the same concentrations of Toc and 
a
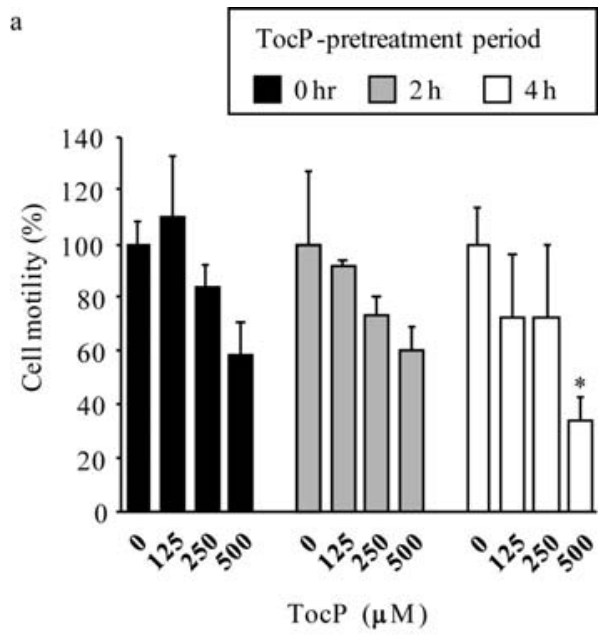

b

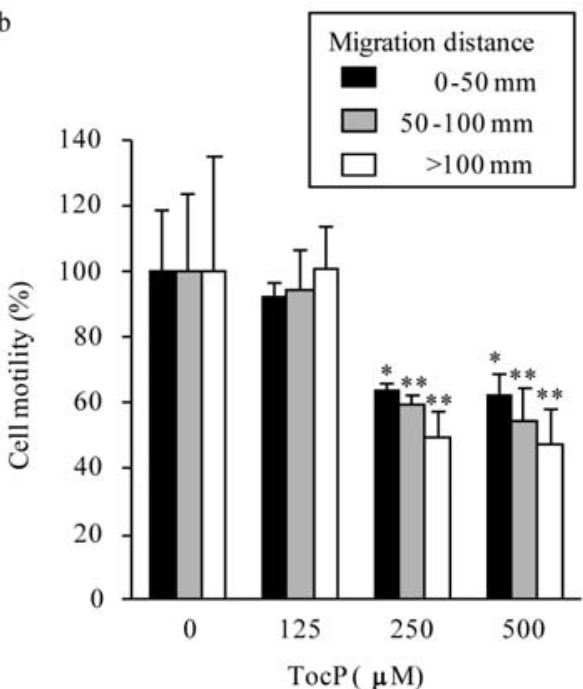

Figure 6. Effects of TocP on cell migratory activity of HT-1080 cells. HT1080 cells were seeded and cultured to reach the confluent monolayer. Then, cells were pre-treated with TocP $(0-500 \mu \mathrm{M})$ for 0,2 , or $4 \mathrm{~h}$, and monolayers were wounded by the definite width, washed, and treated with TocP for $4 \mathrm{~h}$. Cell migration was allowed for $0-4 \mathrm{~h}$, and assessed by counting the number of cells that migrated into allover the denuded area. The number of migrated cells into the denuded area (a). The migration distance of the cells pre-treated with TocP for $4 \mathrm{~h}$ from the wound edge (b). Cell migration levels were divided into three ranks $(0-50 \mu \mathrm{m}, 50-100 \mu \mathrm{m}$ and $>100 \mu \mathrm{m}$ ). Significantly different from $0 \mu \mathrm{M}$ of TocP (the control): " $\mathrm{p}<0.05,{ }^{* *} \mathrm{p}<0.01$.

TocP. On the other hand, the results also showed that intracellular superoxide levels were scarcely diminished by TocP treatment, although the superoxide levels were significantly reduced by Toc treatment $(\mathrm{p}<0.01)$ (Fig. 5c). These findings indicate that TocP suppressed intracellular ROS such as peroxides and lipidperoxides, but not superoxide anion radicals.

Suppressive effects of TocP on cell migratory activity of HT1080 cells. To evaluate the effects of TocP on cell migration, confluent monolayers of HT-1080 cells were scraped in part with a pipette tip to remove a section of the monolayer, and the cells were cultured for 0,2 , or $4 \mathrm{~h}$ with $0-500 \mu \mathrm{M}$ of TocP. The migration rate was assessed by counting the cells that migrated into the pre-defined denuded area of the
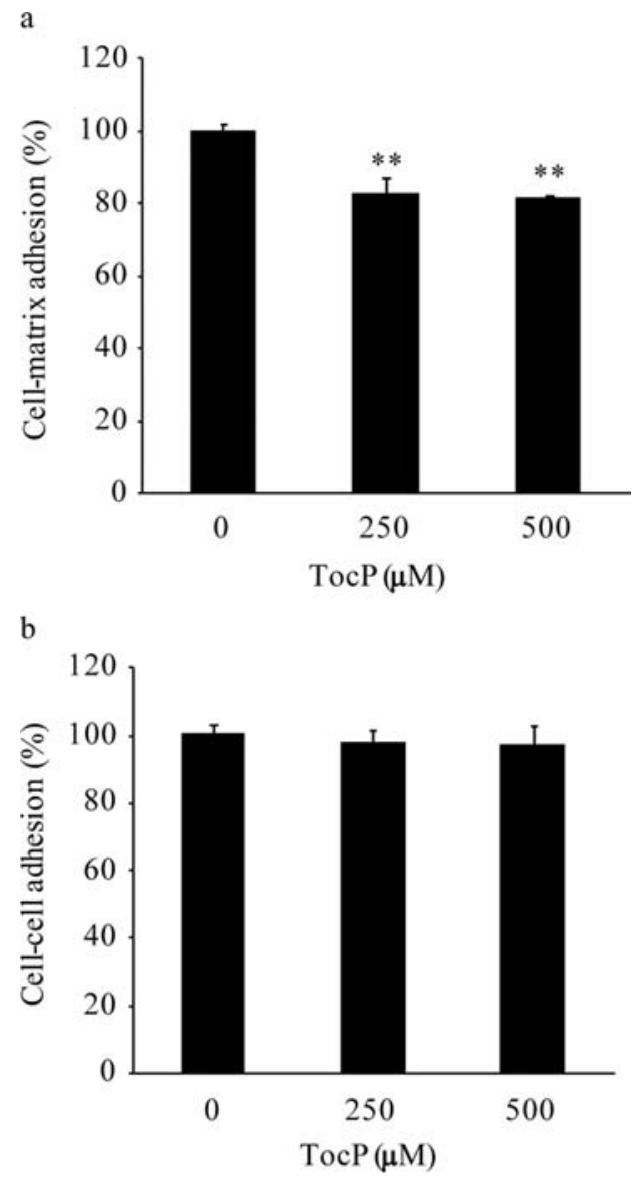

Figure 7. Effects of TocP on the cell-cell and cell-matrix adhesion of HT-1080 cells. Cell-matrix adhesion of HT-1080 cells (a). HT-1080 cells incubated overnight with or without various concentrations of TocP $(0-500 \mu \mathrm{M})$ were seeded onto the 24-well plates coated with Matrigel. After $1 \mathrm{~h}$, attached cells were trypsinized, collected and counted with a particle counter. Significantly different from $0 \mu \mathrm{M}$ of TocP (the control): ${ }^{* *} \mathrm{p}<0.01$. Cell-cell adhesion of HT-1080 cells (b). HT-1080 cells were made to form the confluent monolayer onto a 24 -well plate, and the TocP $(0-500 \mu \mathrm{M})$-treated or nontreated HT-1080 cells were further seeded on the ready-made monolayer. After $1 \mathrm{~h}$, non-adherent cells were collected and counted with a particle counter.

monolayer, and by measuring the distance from the wound edge. The results showed that TocP inhibited the migration of HT-1080 cells in a time- and dose-dependent manner (Fig. 6a), and 250 and $500 \mu \mathrm{M}$ of TocP significantly suppressed cell motility (Fig. 6b).

Effects of TocP on cell-cell and cell-matrix adhesion. Cancer cells invading into the host tissue, are considered to break their cell-cell contacts and in turn construct new contacts with the ECM. Therefore, weak cell-cell adhesion and intense cell-matrix adhesion are known to correlate well with a highly invasive phenotype (19). Hence, the effects of TocP on either the cell-cell or cell-matrix adhesion were examined (20). As shown in Fig. 7a, TocP reduced the cell attachment to the Matrigel in a dose-dependent manner $(\mathrm{p}<0.01)$. On the other hand, TocP treatment did not affect the cell-cell adhesion (Fig. 7b).

Repressive effects of TocP on gelatinase production/ secretion in HT-1080 cells. The secretion of extracellular 

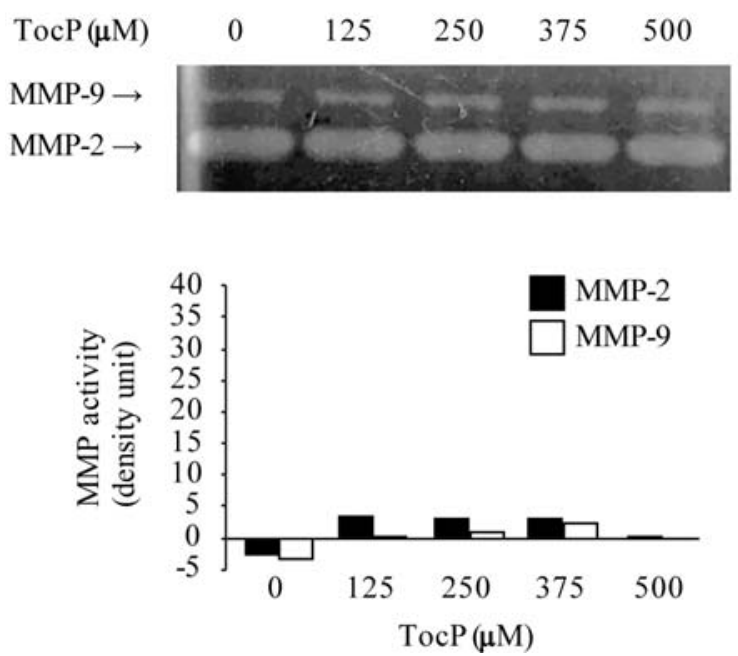

b
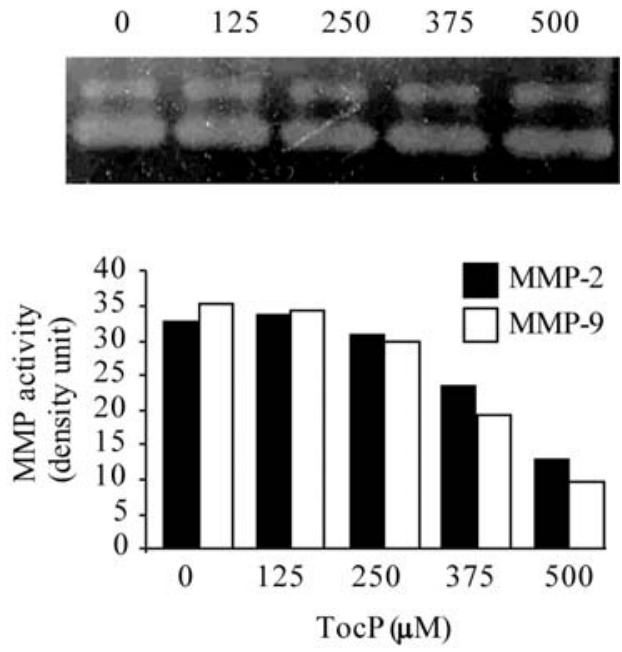

Figure 8. Effects of TocP on gelatinase production/secretion in HT-1080 cells. Cells were detached to form single-cell suspension in culture medium and treated with TocP $(0-500 \mu \mathrm{M})$ or vehicle (comtrol) for $1 \mathrm{~h}$. Treated cells were seeded into a 24 -well plate, and incubated at $37^{\circ} \mathrm{C}$. After (a) $1-$ or (b) $24-\mathrm{h}$ incubation, the supernatants were collected and subjected to a gelatin zymography. The protease activity was visualized as transparent bands within the stained gel, and the electrophorogram was analyzed for densitometry.

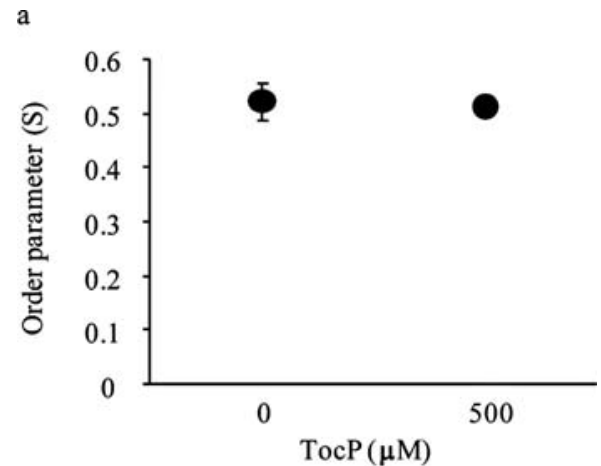

b

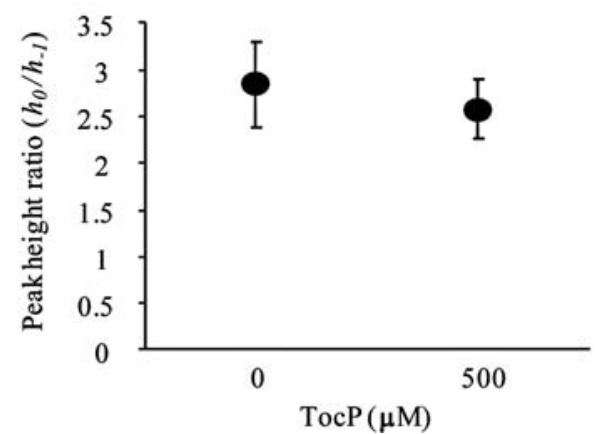

Figure 9. Effects of TocP on cell membrane fluidity of HT-1080 cells. After the treatment with $500 \mu \mathrm{M}$ of TocP, spin labeled 5-DS or 16-DS was added to the cell suspensions and incubated for $45 \mathrm{~min}$ at $37^{\circ} \mathrm{C}$. Then, ESR measurements were performed using an ESR spectrometer. Membrane fluidity is expressed as the order parameter (S) (a) and the ratio of the peak height $\left(h_{0} / h_{-1}\right)$ (b). The greater the values of the $\mathrm{S}$ and the $h_{0} / h_{-1}$, the lesser the freedom of motion of the spin label in biomembrane bilayer, indicating a lower membrane fluidity.

proteases plays an important role in invasion of cancer cells. To investigate whether MMP-2 or MMP-9 activity was associated with anti-invasive activities of TocP, zymogram assay was used to detect the enzymic activity in the culture medium following treatment with various doses of TocP for 1 or $24 \mathrm{~h}$ (Fig. 8a and b). Our results demonstrated that no difference in MMP-2 or MMP-9 activity among diverse doses of TocP was identified for the same periods that for the invasion assay (treatment with TocP for $2 \mathrm{~h}$ ), whereas TocP inhibited MMP-2 and MMP-9 activities in a dose-dependent manner by the prolonged treatment with TocP $(24 \mathrm{~h})$.

Effects of Toc and TocP on membrane fluidity of HT-1080 cells. It was previously suggested that TocP may reduce membrane fluidity $(3,7)$. The effects of TocP on membrane fluidity of HT-1080 cells were monitored. Membrane fluidity was determined using fatty acid spin label agents (5-DS and 16-DS) by ESR. TocP hardly altered the order parameter (S) (Fig. 9a) and peak height ratio $\left(h_{0} / h_{-1}\right)$ (Fig. 9b). This finding showed that TocP did not affect the fluidity at either the shallower or deeper layer of the cell membrane of HT-1080 cells.

Influences of TocP on cell morphology. To investigate the effects of TocP on cell morphology, we observed the TocPtreated human fibrosarcoma HT-1080 cells and human skin dermal fibroblasts DUMS-16 cells with SEM (Fig. 10). In controls (non-treatment with TocP), HT-1080 cells showed a morphology different from that of DUMS-16 cells. HT-1080 cells were generally smaller than DUMS-16, and their morphologies were epithelial-like, but not fibroblast-like. On the other hand, the treatment with TocP induced dynamic morphological changes such as appearances of a lot of spikeshaped processes and vesicles in HT-1080 cells. In contrast, DUMS-16 cells treated with TocP did not show any morphological differences as compared with untreated cells.

Intracellular expression and distribution of cortactin and Factin in TocP-treated HT-1080 cells. Cortactin is suggested 
HT-1080

Control

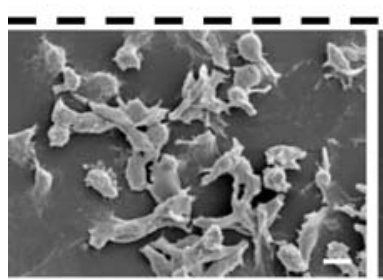

TocP $(500 \mu \mathrm{M})$

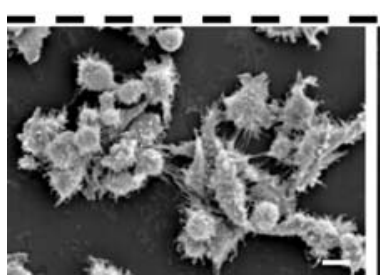

DUMS-16

Control

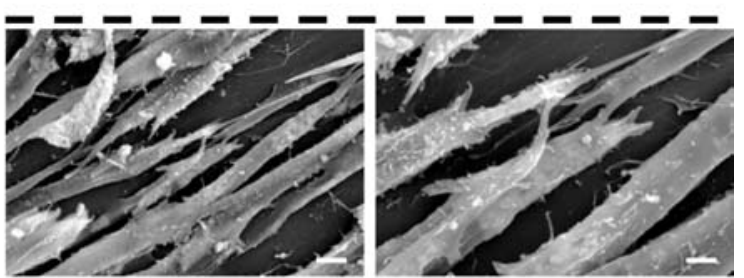

TocP $(500 \mu \mathrm{M})$
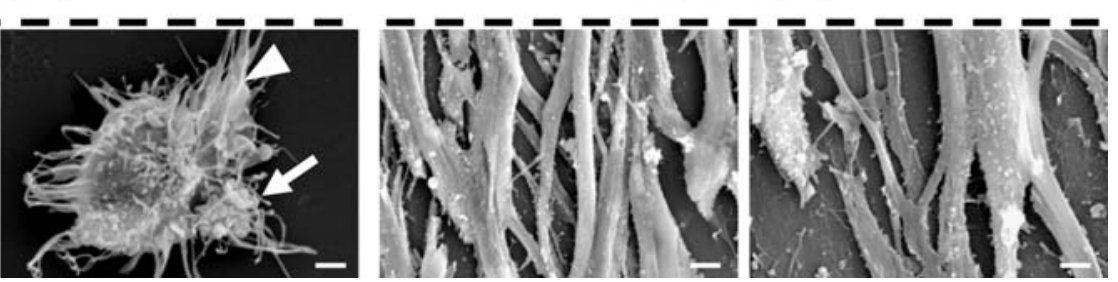

Figure 10. Scanning electron microscopy of human fibrosarcoma HT-1080 or normal fuman fibroblastic DUMS-16 cells treated with or without TocP. HT1080 or DUMS-16 cells were seeded onto the Matrigel-precoated plastic sheets and grown for $24 \mathrm{~h}$. Then cells were treated with $500 \mu \mathrm{M}$ of TocP for $2 \mathrm{~h}$, fixed, and observed with a scanning electron microscope. HT-1080 cells in the control group (top: left, x1000; right, x5000) or TocP-treated group (bottom: left, x1000; right; x5000). DUMS-16 cells in the control group (top: left, x1000; right, x5000) or TocP-treated group (bottom: left, x1000; right, x5000). Arrowhead indicates a spike-shaped process. Arrow indicates a vesicle. The scale bar indicates 10 (x1000) or $2 \mu \mathrm{m}$ (x5000), respectively.

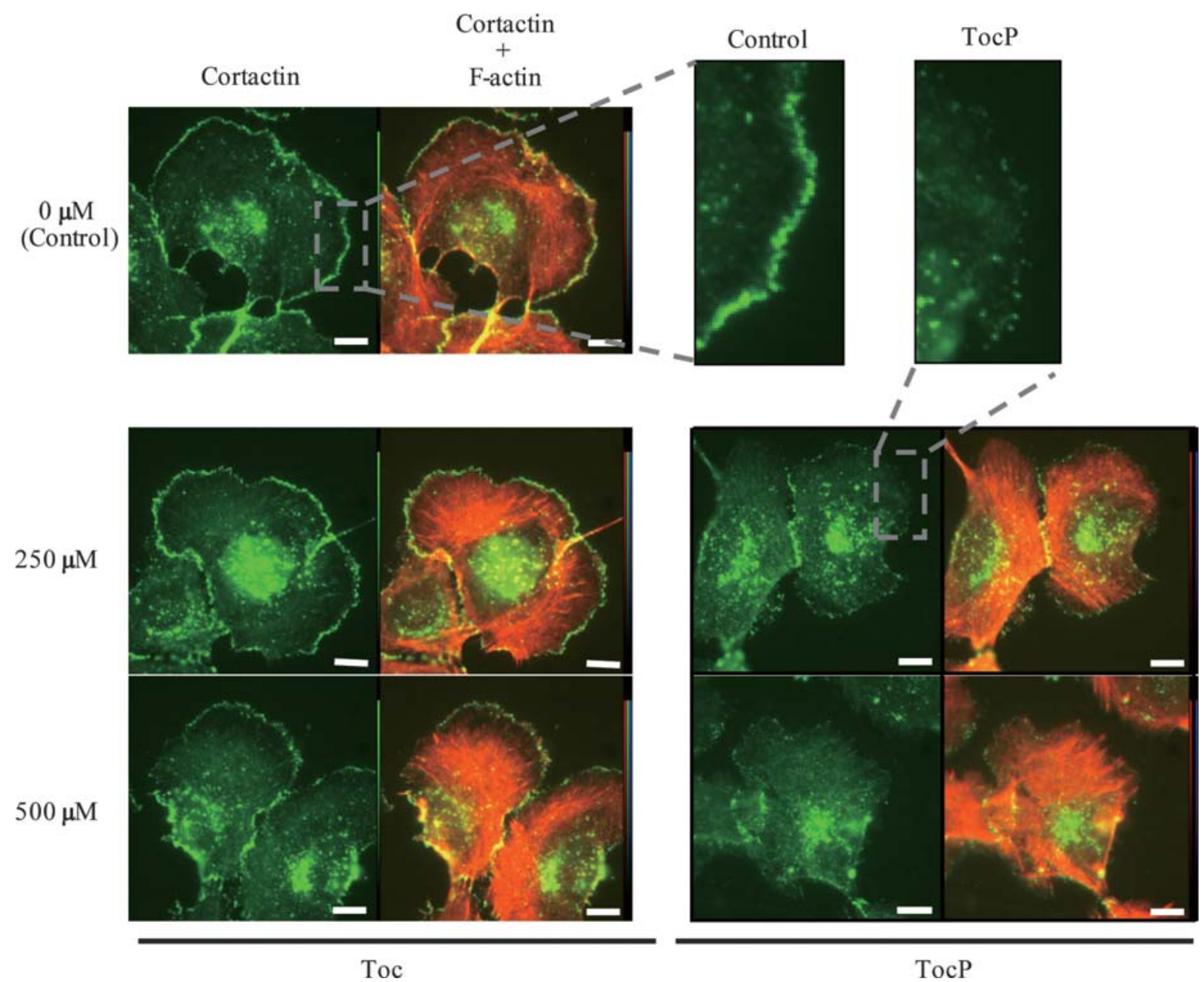

Figure 11. Immunocytochemical detection of cortactin and F-actin in HT-1080 cells. Cells were plated on a chamber slide, grown for $24 \mathrm{~h}$, treated with 0-500 $\mu \mathrm{M}$ of Toc or TocP followed by immunocytochemical staining and indirect fluorescence staining. The FITC-derived fluorescence (cortactin: green) and rhodamine-derived fluorescence (F-actin directed by phalloidin: red) were detected by fluorescence microscopy. The photographs of the top right corner show the enlarged picture of the cellular peripheral area. The scale bar indicates $5 \mu \mathrm{m}$. 

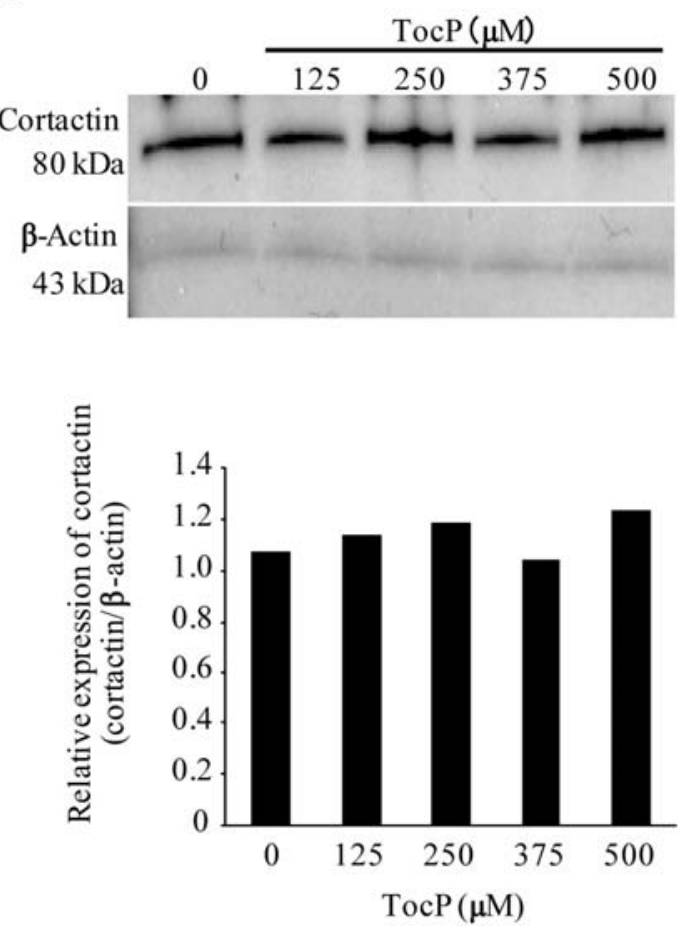

b
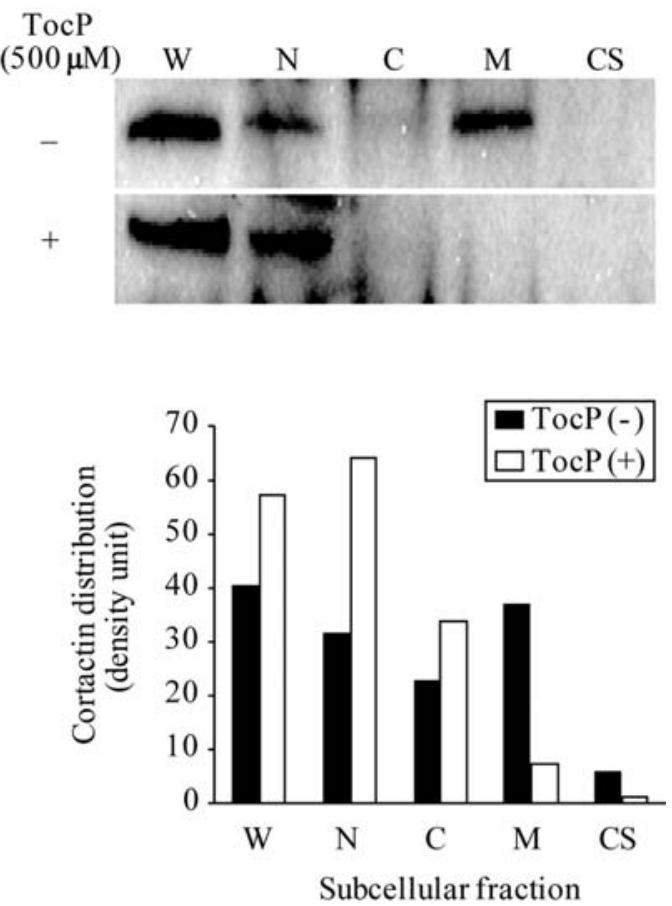

Figure 12. Effects of TocP on protein expression and distribution of cortactin in HT-1080 cells. Dose-dependent effects of TocP on expression of cortactin (a). Cellular proteins were extracted immediately after TocP $(0-500 \mu \mathrm{M})$ treatment, and subjected to Western blotting (top) and densitometric analysis (bottom) for cortactin expression. $\beta$-actin was used as a loading control. Effect of TocP on distribution of cortactin (b). Cellular proteins were extracted immediately after TocP $(0$ or $500 \mu \mathrm{M})$ treatment. The extracted proteins were subcellular-fractionized, and subjected to Western blotting (top) and densitometric analysis (bottom) for cortactin expression. W, whole cell; N, nucleus; C, cytoplasm; M, plasma membrane; CS, cytoskeleton.

to be localized and to function at invadopodia, which is known as actin-rich protrusions associated with degradation of ECM and tumor invasion (21). To confirm the expression of cortactin and F-actin (filamentous actin) proteins, we conducted immunocytochemical staining and indirect staining, and observed the distribution of cortactin and Factin. In non-treated (the control) cells, cortactin was widely scattered in the cytoplasm and strongly expressed particularly in the nucleus and plasma membrane at the cellular peripheral area (Fig. 11). After treatment with TocP, cortactin disappeared from membrane in a dose-dependent manner, whereas the distribution was not changed by treatment with Toc. The distribution of F-actin was scarcely altered despite Toc or TocP treatment.

Effects of TocP on protein expression and distribution of cortactin in HT-1080 cells. Based on immunocytochemical expression analysis, we further examined the protein levels of cortactin using Western blots and densitometry (Fig. 12). The results of Western blotting assay suggested that no concentration of TocP treatment for $1 \mathrm{~h}$ was able to change the expression of cortactin protein in the whole cell level (Fig. 12a). Subcellular distribution of cortactin was also examined by Western blotting, and the results indicated that cortactin in non-treated cells was mainly expressed in the plasma membrane and weakly distributed in the nucleus (Fig. 12b). However, the membrane localization of cortactin was drastically altered after TocP treatment. The results revealed that the cortactin expression in the plasma membrane was notably decreased, and the expression in the nucleus was increased after 1-h TocP treatment. Thus, these results suggested that cortactin molecules were largely translocated from the plasma membrane to the nucleus by TocP treatment. The results of the cell fractionation experiments are consistent with the apparent lack of localization of cortactin at the cellular peripheral area in the immunofluorescence studies.

\section{Discussion}

Direct major causes of cancer patient mortality are tumor invasion and metastasis, which need to be overcome for cancer-recurrence prevention and cancer therapy (11). During metastasis, tumor cells invade the surrounding ECM, migrate into the bloodstream, and traverse endothelial barriers at the secondary sites in distant organs (22). Therefore, the invasion of tumor cells through the BM is a crucial step in the occurrence of metastasis. In the present study, we examined whether TocP can suppress the invasion of human fibrosarcoma HT-1080 cells.

The results showed that TocP markedly decreased the invasiveness of HT-1080 cells as compared with several other Toc derivatives examined (Fig. 2), and the inhibitory effects of TocP were exerted in a dose-dependent manner (Fig. 3). On the other hand, no cytotoxic effects on either HT-1080 cells or human skin dermal fibroblasts DUMS-16 cells were induced by the TocP treatments at doses up to $500 \mu \mathrm{M}$ (Fig. 4). These results suggest that TocP preferentially acts on tumor cells without injuring the normal cells. Additionally, these results suggest that the repressive effects of TocP on tumor invasion are mainly related to 
suppression of the invasive process itself, but not the secondary effects through suppression of cell growth or induction of cell deaths.

Various Toc derivatives have been studied to date, and for example, two Toc analogues, TocS and TocA, have been shown to have potent anti-cancer properties in cell culture and preclinical animal studies (23-28), and TocP has been also shown to induce cell death, to inhibit cell proliferation and to provoke apoptosis in the osteosarcoma cell line MG-63 (3). However, our results demonstrate that TocS and TocA could not repress tumor invasion, and TocP also could not induce inhibition of cell proliferation and apoptosis, unlike previous reports (3). These differences seem to be attributed to the treatment periods that tumor cells made contact with Toc derivatives or differences of cell types. In other words, TocP can exert inhibitory effects on tumor invasion despite a short-time period of treatment. Therefore, it is suggested that this inhibitory effect of TocP on tumor invasion is a novel effect different from the anti-cancer activities previously known in other Toc derivatives.

It has been reported that human tumor cells produce ROS more abundantly than non-transformed cell lines (29), and an elevated oxidative stress has been found in various types of cancer cells (30). Several lines of evidence suggest that ROS are related to diverse abilities of cancer cells which increase cell proliferation, DNA synthesis (31), survival, cellular migration (32), invasion $(33,34)$, tumor metastasis $(35,36)$ and angiogenesis (37). Furthermore, ROS in cells act as the second messengers and play important roles in intracellular signaling cascades, which induce and maintain the oncogenic phenotype of cancer cells (29). On the other hand, it is also known that antioxidants can inhibit tumor cell proliferation $(13,38,39)$, invasion and metastasis $(14,40,41)$. Thus, these findings suggest the possibility that scavenging of ROS by antioxidant materials can suppress the tumorigenic actions of ROS and the development of certain cancers.

Toc is a well-known antioxidant (42), so that TocP, which is a derivative of Toc, is expected to exhibit an excellent antioxidant activity due to its stability. Our results demonstrate that the repressive effects of TocP on intracellular ROS production such as peroxides and lipidperoxides are nearly equal or inferior to Toc (Fig. 5), though Toc does not exert anti-invasive activity (Fig. 2). Thus, it seems that the antioxidant activities of TocP are not mainly involved in the repressive effects on tumor invasion, and the anti-invasive effect of TocP seems to be due to the effect of the parent compound Toc. It has been also shown that TocP is highly resistant to hydrolysis by both chemical and enzymatic actions, which indicates that its effect is not related to the hydrolytic conversion to free tocopherol $(4,7,9,10,43)$. Furthermore, it was shown that TocP has a more marked potency than the non-esterified molecule in several studies (4,8-10). In addition, a previous study indicates that TocP forms a barrier that might inhibit the transfer of radicals from one polyunsaturated fatty acid to another, so that TocP has a potent antioxidant effect of its own, but not due to the conversion into Toc (7). Thus, our results indicate the possibility that the active form of tocopherol may be tocopheryl phosphate similarly to previous studies $(4,9)$.
Tumor cell migration based on its motility is required for the cells to invade and metastasize (44), and the spreading of tumor cells from the primary site to a distant organ usually occur through an active process involving the loss of cell-cell adhesion and the subsequent gain of cell-matrix interaction (19). Our results showed that TocP inhibited the migration of HT-1080 cells in a dose-dependent manner (Fig. 6), and TocP inhibited the attachment of HT-1080 cells to the ECM Matrigel in a dose-dependent manner, but did not inhibit cell-cell adhesion (Fig. 7). The binding of the malignant cells to matrix proteins in the BM allows their attachment and activates their invasiveness, and cellular interactions with the ECM, which promotes adhesion and migration, are believed to be essential for the primary tumor invasion, migration, and metastasis (45). These results suggest that inhibition of cell migratory activity and down-regulation of cell-matrix interaction by TocP may be a crucial event in the TocPinduced suppression of invasion of HT-1080 cells.

In tumor invasion, tumor cells that escape from the tumor mass degrade the surrounding ECM. A variety of proteases produced by tumor cells are implicated in ECM degradation. Invasion of tumor cells through the ECM and BM barriers is a crucial step in tumor dissemination and metastasis $(46,47)$. The extracellular secretion of proteinases such as MMPs plays an important role in migration and invasion of cancer cells (47-50). Especially, MMP-2 and MMP-9 are well known as decomposing enzymes for type-IV collagen, which is an important component of the BM. Tumor cells can decompose type-IV collagen and penetrate the BM through secreting of MMP-2 and MMP-9, therefore the activities of MMP-2 and MMP-9 in tumor cells are related to their invading ability. Our result demonstrated that TocP could not affect the MMP-2 or MMP-9 production/secretion in the same periods of invasive assay (treatment with TocP for $2 \mathrm{~h}$ ), whereas TocP could inhibit MMP-2 and MMP-9 activities in a dose-dependent manner by the prolonged treatment with TocP (24 h) (Fig. 8). Therefore, our results suggested that the repressive effect of TocP on tumor invasion for a short-term treatment is not related to MMPs production/secretion, and also suggest that the prolonged treatment with TocP might exert more potent anti-invasiveness via inhibition of MMP secretion.

TocP has a hydrophilic polar phosphate group attached to the chroman head and the hydrophobic hydrocarbon tail (Fig. 1). This may enable TocP to be incorporated into biomembranes in such a way that its polar lipophobic phosphate group is located at the water-membrane interface, and that the lipophilic hydrocarbon chain tail is embedded inside the lipid membrane. Furthermore, these characteristics may also endow TocP with a detergent activity, thereby TocP seems to act as a detergent and alter membrane fluidities of cells (7). In fact, it has been shown that TocP induced hemolysis of erythrocytes as compared with Toc, Trolox, TocA and TocS $(3,7)$, and also suggested that TocP induced cell death and inhibited cell proliferation in the osteosarcoma cell line MG-63 due to a membrane destabilizing activity by acting as a detergent (3). In addition, it was shown that TocP reduced membrane fluidity of erythrocytes, in contrast to Toc (7). Thus, these findings imply the possibility that the various biological efficacies of TocP are associated with the modu- 
lation of membrane stability. However, no significant cytotoxic effects and alteration of membrane fluidities were found in our results (Figs. 4 and 9). On the other hand, our results demonstrate that the treatment with TocP induced dynamic morphological changes such as appearance of abundant spike-shaped processes and vesicles in HT-1080 cells, whereas DUMS-16 cells treated with TocP did not show any morphological differences from untreated cells. These data indicate that TocP preferentially induces morphological changes in HT-1080 fibrosarcoma cells, although TocP does not markedly affect membrane fluidity and cell viability. Therefore, the results indicate that the repressive effects of TocP on tumor invasion may be related to the TocP-induced morphological changes via detergent action of TocP.

Tumor cells use actin-rich protrusions called invadopodia to degrade ECM and invade through tissues (51-54). Recently, a role of cortactin in promoting cell motility and invasion has been focused on $(21,55)$. Cortactin is an actin-binding protein and a critical component of invadopodia (51), and cortactin is overexpressed in many types of human cancers, including head and neck and esophageal squamous carcinomas, colorectal, gastric, hepatocellular, breast and ovarian cancers (56-60). Furthermore, the overexpression of cortactin has been shown to enhance cell motility in a variety of assays, including transwell migration $(61,62)$, wound closure $(63,64)$ and single cell motility (61). Accordingly, cortactin is frequently used as an invadopodia marker, based on its strong localization to sites of focal ECM degradation (21). Our results clearly demonstrated that TocP affected cortactin distribution in HT-1080 cells by both immunocytochemical detection (Fig. 11) and Western blotting (Fig. 12). Cortactin markedly disappeared from the plasma membrane, and in turn was strongly expressed in the nucleus after TocP treatment. Since the total expression levels of cortactin in whole cells were not changed, and the effects were not detected by Toc treatment, these results suggested that cortactin molecules were largely translocated from the plasma membrane to the nucleus by TocP treatment.

Previous studies suggested that the TocP transport into cells may occur via organic anion transporters (OAT) (43), and TocP may act as a signaling molecule $(4,5)$. It has been reported that supplementation with TocP affects the several signaling molecules such as anti-apoptotic p42/44 ERK kinase, p38 MAPKß, pro-apoptotic proteins p38 MAPK $\alpha$, JNK, DNA binding of the redox-sensitive transcriptional factor $\mathrm{NFKB}$, anti-death protein $\mathrm{Bcl}-2$ and survival signaling protein Akt (5). In addition, cortactin is post-translationally modified by many different kinases, including the tyrosine kinases, src, fer, abl, fyn, syk and met, along with the serine/threonine kinases Erk, PAK and MLCK $(65,66)$. Therefore, we predict that TocP, when transported into cells, suppresses the cortactin localization to invadodia by acting as a signaling molecule.

In conclusion, this study is the first to report on the effectiveness of TocP as an inhibitor of tumor invasion. The present study also suggests that the repressive effects of TocP on tumor invasion are through decrease in cell motility, repression of adhesion to the ECM, morphological changes and alteration of cortactin distribution, which are probably due to acting as signaling molecules and/or detergents. Therefore, TocP is suggested to be a possible candidate for controlling tumor invasion and deserve further investigations, both looking at its detailed mechanism of action and its effect in animals and humans.

\section{Acknowledgements}

The authors thank Showa Denko Co. Ltd. for the gift of samples of sodium $\alpha$-tocopheryl phosphate (TocP).

\section{References}

1. Gianello R, Libinaki R, Azzi A, et al: Alpha-tocopheryl phosphate: a novel, natural form of vitamin E. Free Radic Biol Med 39: 970-976, 2005.

2. Libinaki R, Ogru E, Gianello R, Bolton L and Geytenbeek S: Evaluation of the safety of mixed tocopheryl phosphates (MTP) a formulation of alpha-tocopheryl phosphate plus alpha-ditocopheryl phosphate. Food Chem Toxicol 44: 916-932, 2006.

3. Rezk BM, van der Vijgh WJ, Bast A and Haenen GR: Alphatocopheryl phosphate is a novel apoptotic agent. Front Biosci 12: 2013-2019, 2007.

4. Negis Y, Zingg JM, Ogru E, Gianello R, Libinaki R and Azzi A: On the existence of cellular tocopheryl phosphate, its synthesis, degradation and cellular roles: a hypothesis. IUBMB Life 57: 23-25, 2005.

5. Mukherjee S, Lekli I, Das M, Azzi A and Das DK: Cardioprotection with alpha-tocopheryl phosphate: amelioration of myocardial ischemia reperfusion injury is linked with its ability to generate a survival signal through Akt activation. Biochim Biophys Acta 1782: 498-503, 2008.

6. Nakayama S, Katoh EM, Tsuzuki T and Kobayashi S: Protective effect of alpha-tocopherol-6-O-phosphate against ultraviolet B-induced damage in cultured mouse skin. J Invest Dermatol 121: 406-411, 2003.

7. Rezk BM, Haenen GR, Van Der Vijgh WJ and Bast A: The extraordinary antioxidant activity of vitamin $\mathrm{E}$ phosphate. Biochim Biophys Acta 1683: 16-21, 2004.

8. Munteanu A, Zingg JM, Ogru E, et al: Modulation of cell proliferation and gene expression by alpha-tocopheryl phosphates: relevance to atherosclerosis and inflammation. Biochem Biophys Res Commun 318: 311-316, 2004.

9. Negis Y, Aytan N, Ozer N, et al: The effect of tocopheryl phosphates on atherosclerosis progression in rabbits fed with a high cholesterol diet. Arch Biochem Biophys 450: 63-66, 2006.

10. Ogru E, Libinaki R, Gianello R, et al: Modulation of cell proliferation and gene expression by alpha-tocopheryl phosphates: relevance to atherosclerosis and inflammation. Ann NY Acad Sci 1031: 405-411, 2004.

11. Shevde LA and Welch DR: Metastasis suppressor pathways - an evolving paradigm. Cancer Lett 198: 1-20, 2003.

12. Rasheed S, Nelson-Rees WA, Toth EM, Arnstein P and Gardner MB: Characterization of a newly derived human sarcoma cell line (HT-1080). Cancer 33: 1027-1033, 1974.

13. Saitoh Y, Okayasu H, Xiao L, Harata Y and Miwa N: Neutral $\mathrm{pH}$ hydrogen-enriched electrolyzed water achieves tumorpreferential clonal growth inhibition over normal cells and tumor invasion inhibition concurrently with intracellular oxidant repression. Oncol Res 17: 247-255, 2008.

14. Liu JW, Nagao N, Kageyama K and Miwa N: Anti-metastatic effect of an autooxidation-resistant and lipophilic ascorbic acid derivative through inhibition of tumor invasion. Anticancer Res 20: 113-118, 2000.

15. Takahashi M, Shibata M and Niki E: Estimation of lipid peroxidation of live cells using a fluorescent probe, diphenyl-1pyrenylphosphine. Free Radic Biol Med 31: 164-174, 2001.

16. Schrenzel J, Serrander L, Banfi B, et al: Electron currents generated by the human phagocyte NADPH oxidase. Nature 392: 734-737, 1998.

17. Sato Y and Rifkin DB: Autocrine activities of basic fibroblast growth factor: regulation of endothelial cell movement, plasminogen activator synthesis, and DNA synthesis. J Cell Biol 107: 1199-1205, 1988.

18. Tsuda K, Kimura K and Nishio I: Leptin improves membrane fluidity of erythrocytes in humans via a nitric oxide-dependent mechanism - an electron paramagnetic resonance investigation. Biochem Biophys Res Commun 297: 672-681, 2002. 
19. Bohle AS and Kalthoff H: Molecular mechanisms of tumor metastasis and angiogenesis. Langenbecks Arch Surg 384: 133-140, 1999.

20. Park MJ, Lee JY, Kwak HJ, et al: Arsenic trioxide $\left(\mathrm{As}_{2} \mathrm{O}_{3}\right)$ inhibits invasion of HT1080 human fibrosarcoma cells: role of nuclear factor-kappaB and reactive oxygen species. J Cell Biochem 95: 955-969, 2005.

21. Weaver AM: Cortactin in tumor invasiveness. Cancer Lett 265: 157-166, 2008

22. Condeelis J, Singer RH and Segall JE: The great escape: when cancer cells hijack the genes for chemotaxis and motility. Annu Rev Cell Dev Biol 21: 695-718, 2005.

23. Kline K, Lawson KA, Yu W and Sanders BG: Vitamin E and cancer. Vitam Horm 76: 435-461, 2007.

24. Qian M, Kralova J, Yu W, et al: c-Jun involvement in vitamin E succinate induced apoptosis of reticuloendotheliosis virus transformed avian lymphoid cells. Oncogene 15: 223-230, 1997.

25. Neuzil J, Svensson I, Weber T, Weber C and Brunk UT: alphatocopheryl succinate-induced apoptosis in Jurkat T cells involves caspase- 3 activation, and both lysosomal and mitochondrial destabilisation. FEBS Lett 445: 295-300, 1999.

26. Neuzil J, Weber T, Schroder A, et al: Induction of cancer cell apoptosis by alpha-tocopheryl succinate: molecular pathways and structural requirements. FASEB J 15: 403-415, 2001.

27. Neuzil J, Zhao M, Ostermann G, et al: Alpha-tocopheryl succinate, an agent with in vivo anti-tumour activity, induces apoptosis by causing lysosomal instability. Biochem $\mathrm{J} 362$ 709-715, 2002.

28. Neuzil J, Dong LF, Ramanathapuram L, et al: Vitamin E analogues as a novel group of mitocans: anti-cancer agents that act by targeting mitochondria. Mol Aspects Med 28: 607-645, 2007.

29. Szatrowski TP and Nathan CF: Production of large amounts of hydrogen peroxide by human tumor cells. Cancer Res 51: 794-798, 1991.

30. Behrend L, Henderson G and Zwacka RM: Reactive oxygen species in oncogenic transformation. Biochem Soc Trans 31: $1441-1444,2003$

31. Amstad P, Crawford D, Muehlematter D, Zbinden I, Larsson R and Cerutti P: Oxidants stress induces the proto-oncogenes, Cfos and C-myc in mouse epidermal cells. Bull Cancer 77: 501-502, 1990.

32. Storz P: Reactive oxygen species in tumor progression. Front Biosci 10: 1881-1896, 2005.

33. Zhang G, Miura Y and Yagasaki K: Suppression of adhesion and invasion of hepatoma cells in culture by tea compounds through antioxidative activity. Cancer Lett 159: 169-173, 2000.

34. Gunther S, Ruhe C, Derikito MG, Bose G, Sauer H and Wartenberg M: Polyphenols prevent cell shedding from mouse mammary cancer spheroids and inhibit cancer cell invasion in confrontation cultures derived from embryonic stem cells. Cancer Lett 250: 25-35, 2007.

35. Mukai M, Shinkai K, Tateishi R, Mori Y and Akedo H: Macrophage potentiation of invasive capacity of rat ascites hepatoma cells. Cancer Res 47: 2167-2171, 1987.

36. Nonaka Y, Iwagaki H, Kimura T, Fuchimoto S and Orita K: Effect of reactive oxygen intermediates on the in vitro invasive capacity of tumor cells and liver metastasis in mice. Int $\mathrm{J}$ Cancer 54: 983-986, 1993

37. Maulik N: Redox signaling of angiogenesis. Antioxid Redox Signal 4: 805-815, 2002

38. Kageyama K, Onoyama Y, Otani S, Matsui-Yuasa I, Nagao N and Miwa N: Enhanced inhibitory effects of hyperthermia combined with ascorbic acid on DNA synthesis in Ehrlich ascites tumor cells grown at a low cell density. Cancer Biochem Biophys 14: 273-280, 1995.

39. Valko M, Leibfritz D, Moncol J, Cronin MT, Mazur M and Telser J: Free radicals and antioxidants in normal physiological functions and human disease. Int J Biochem Cell Biol 39: 44-84, 2007.

40. Liu JW, Nagao N, Kageyama K and Miwa N: Antimetastatic and anti-invasive ability of phospho-ascorbyl palmitate through intracellular ascorbate enrichment and the resultant antioxidant action. Oncol Res 11: 479-487, 1999.

41. Nagao N, Nakayama T, Etoh T, Saiki I and Miwa N: Tumor invasion is inhibited by phosphorylated ascorbate via enrichment of intracellular vitamin $\mathrm{C}$ and decreasing of oxidative stress. J Cancer Res Clin Oncol 126: 511-518, 2000.

42. Burton GW, Joyce A and Ingold KU: First proof that vitamin E is major lipid-soluble, chain-breaking antioxidant in human blood plasma. Lancet 2: 327, 1982.
43. Negis Y, Meydani M, Zingg JM and Azzi A: Molecular mechanism of alpha-tocopheryl-phosphate transport across the cell membrane. Biochem Biophys Res Commun 359: 348-353, 2007.

44. Wells A: Tumor invasion: role of growth factor-induced cell motility. Adv Cancer Res 78: 31-101, 2000.

45. Werb Z: ECM and cell surface proteolysis: regulating cellular ecology. Cell 91: 439-442, 1997.

46. Birkedal-Hansen $\mathrm{H}$ : Proteolytic remodeling of extracellular matrix. Curr Opin Cell Biol 7: 728-735, 1995.

47. Johnsen M, Lund LR, Romer J, Almholt K and Dano K: Cancer invasion and tissue remodeling: common themes in proteolytic matrix degradation. Curr Opin Cell Biol 10: 667-671, 1998.

48. Mignatti $P$ and Rifkin DB: Biology and biochemistry of proteinases in tumor invasion. Physiol Rev 73: 161-195, 1993.

49. MacDougall JR and Matrisian LM: Contributions of tumor and stromal matrix metalloproteinases to tumor progression, invasion and metastasis. Cancer Metastasis Rev 14: 351-362, 1995.

50. Kahari VM and Saarialho-Kere U: Matrix metalloproteinases and their inhibitors in tumour growth and invasion. Ann Med 31: 34-45, 1999

51. Weaver AM: Invadopodia: specialized cell structures for cancer invasion. Clin Exp Metastasis 23: 97-105, 2006.

52. Linder S: The matrix corroded: podosomes and invadopodia in extracellular matrix degradation. Trends Cell Biol 17: 107-117, 2007.

53. Gimona M, Buccione R, Courtneidge SA and Linder S: Assembly and biological role of podosomes and invadopodia. Curr Opin Cell Biol 20: 235-241, 2008.

54. Machesky L, Jurdic P and Hinz B: Grab, stick, pull and digest: the functional diversity of actin-associated matrix-adhesion structures. Workshop on invadopodia, Podosomes and focal adhesions in tissue invasion. EMBO Rep 9: 139-143, 2008.

55. Ayala I, Baldassarre M, Giacchetti G, et al: Multiple regulatory inputs converge on cortactin to control invadopodia biogenesis and extracellular matrix degradation. J Cell Sci 121: 369-378, 2008.

56. Myllykangas S, Bohling T and Knuutila S: Specificity, selection and significance of gene amplifications in cancer. Semin Cancer Biol 17: 42-55, 2007

57. Rodrigo JP, Garcia LA, Ramos S, Lazo PS and Suarez C: EMS1 gene amplification correlates with poor prognosis in squamous cell carcinomas of the head and neck. Clin Cancer Res 6: 3177-3182, 2000.

58. Hui R, Ball JR, Macmillan RD, et al: EMS1 gene expression in primary breast cancer: relationship to cyclin D1 and oestrogen receptor expression and patient survival. Oncogene 17: 1053-1059, 1998

59. Luo ML, Shen XM, Zhang Y, et al: Amplification and overexpression of CTTN (EMS1) contribute to the metastasis of esophageal squamous cell carcinoma by promoting cell migration and anoikis resistance. Cancer Res 66: 11690-11699, 2006.

60. Yuan BZ, Zhou X, Zimonjic DB, Durkin ME and Popescu NC: Amplification and overexpression of the EMS 1 oncogene, a possible prognostic marker, in human hepatocellular carcinoma. J Mol Diagn 5: 48-53, 2003.

61. Bryce NS, Clark ES, Leysath JL, Currie JD, Webb DJ and Weaver AM: Cortactin promotes cell motility by enhancing lamellipodial persistence. Curr Biol 15: 1276-1285, 2005.

62. Patel AS, Schechter GL, Wasilenko WJ and Somers KD: Overexpression of EMS1/cortactin in NIH3T3 fibroblasts causes increased cell motility and invasion in vitro. Oncogene 16: 3227-3232, 1998

63. Kowalski JR, Egile C, Gil S, Snapper SB, Li R and Thomas SM: Cortactin regulates cell migration through activation of $\mathrm{N}$ WASP. J Cell Sci 118: 79-87, 2005.

64. Huang C, Liu J, Haudenschild CC and Zhan X: The role of tyrosine phosphorylation of cortactin in the locomotion of endothelial cells. J Biol Chem 273: 25770-25776, 1998.

65. Lua BL and Low BC: Cortactin phosphorylation as a switch for actin cytoskeletal network and cell dynamics control. FEBS Lett 579: 577-585, 2005

66. Boyle SN, Michaud GA, Schweitzer B, Predki PF and Koleske AJ: A critical role for cortactin phosphorylation by Abl-family kinases in PDGF-induced dorsal-wave formation. Curr Biol 17: 445-451, 2007. 